\section{Tore Sanner}

tore.sanner@kjemi.uio.no

Tom K. Grimsrud

Tore Sanner (f. 1935) er professor emeritus. Han var tidligere forskningssjef ved Institutt for kreftforskning, Radiumhospitalet, og professor II ved Kjemisk institutt, Universitetet i Oslo.

Ingen oppgitte interessekonflikter.

Tom K. Grimsrud (f. 1955) er dr.med., spesialist i arbeidsmedisin og overlege/forsker ved Kreftregisteret.

Ingen oppgitte interessekonflikter.

\section{Litteratur}

1. Royal Society for Public Health (RSPH). Stopping smoking by using other sour ces of nicotine (2015, august). www.rsph.org.uk/filemanager/root/site_assets/ our_work/position_statements/rsph_smoking_positional_final.pdf (14.8.2015).

2. Sanner T, Grimsrud TK. Nicotine: carcinogenicity and effects on response to cancer treatment - A review. Front Oncol 2015; 5: 196. doi: 10.3389/ fonc.2015.00196. (in press).

3. Östenson CG, Hilding A, Grill V et al. High consumption of smokeless tobacco [«snus») predicts increased risk of type 2 diabetes in a 10-year prospective study of middle-aged Swedish men. Scand J Public Health 2012; 40: 730-7.

\section{Re: Våre utenlandske kolleger}

Det er fortjenestefullt at Tidsskriftet fokuserer på utenlandske legers opplevelser med å arbeide i Norge, i form av to originalartikler $(1,2)$ og en lederartikkel $(3)$ i sommerutgaven. Jeg har en liten kommentar, eller kanskje mer en digresjon, til lederartikkelen, nærmere bestemt lederartikkelens tittel: «Våre utenlandske kolleger», et begrep som også er nevnt et par ganger i selve teksten.

Tittelen virker å være en (intensjonell eller ikke-intensjonell) variant av uttrykket «våre nye landsmenn». Begrepet har sine røtter fra kong Olavs nyttårstale i 1982 (4): «Kjære landsmenn, La meg først få si at med disse gode, gamle ord mener jeg alle mine landsmenn, også de som er blitt norske statsborgere og dermed våre landsmenn efter å ha valgt Norge som sitt nye hjemland». Begrepet har senere også blitt brukt av kong Harald (5), og har vært ment som en inkluderende og samlende formulering. Begrepet brukes dog «stort sett ironisk og anbefales ikke» i NRKs flerkulturelle ordliste (6).

To landslagssjefer i fotball har tilfeldigvis også blitt koblet til begrepet; Drillo som sa at «våre nye landsmenn drar jo ikke på påskeferie, hiv dem inn her» som en løsning på folketomme tribuner på Ullevål før en kvalikkamp i 2013 (7), og Even Pellerud som mente at «i Norge snakkes det fortsatt om «våre nye landsmenn» og det gjøres et stort nummer ut av hvor folk kommer fra» under fotball-VM i Canada i år (8).

Jeg tror nok at «våre utenlandske kolleger» på samme måte som «våre nye landsmenn» skaper mer avstand («oss» og «dem») enn inklusjon, stikk i strid med kong Olavs gode intensjoner.

\section{Kashif Waqar Faiz}

kashif.faiz@medisin.uio.no

Kashif Waqar Faiz (f. 1978) er avdelingssjef og overlege ved Akershus universitetssykehus.

Ingen oppgitte interessekonflikter

\section{Litteratur}

1. Sandbu M, Kamps A, Preljevic V et al. Utenlandske leger i norsk psykiatri behov for en mentorordning? Tidsskr Nor Legeforen 2015: 135: 1133-7.

2. Skjeggestad E, Sandal GM, Gulbrandsen P. Utenlandske legers opplevelse av å begynne i yrket i Norge. Tidsskr Nor Legeforen 2015; 135: 1129-32.

3. Shaygani S. Våre utenlandske kolleger. Tidsskr Nor Legeforen 2015; 135: 1104 4. Nyttårstalen. 1982. www.kongehuset.no/tale.html?tid=70919\&sek=26947\&scope $=0$ (7.7.2015).

5. Nyttårstalen. 1998. www. kongehuset.no/tale.html?tid=76343\&sek=26947 (7.7.2015)
6. NRKs flerkulturelle ordliste. http://fido.nrk.no/22d22e5cb682284d0e8f7cb5b 5f5addd3aad59fc3c4765bb807b7de9c13a9c2d/svartelista\%20a5\%20bokm\%c3\% A5l.pdf (7.7.2015).

7. Hiv våre nye landsmenn inn her. Dagbladet 20.03.2013. www.dagbladet.no/2013/ 03/20/sport/fotball/landslaget/drillo/26307016/ (7.7.2015).

8. Pellerud mener det hvite landslaget viser et problem i det norske samfunnet. Aftenposten 17.6.2015. www.aftenposten.no/100Sport/fotball/kvinner/ Landslagssjefen-er-lei-av-uttrykket-vare-nye-landsmenn--553828_1.snd (7.7.2015)

\section{S. Shaygani svarer:}

Takk for en interessant og våken kommentar. Umiddelbart hadde jeg lyst til å spørre om du har et bedre begrep som kan være mer inkluderende, men så kom jeg på følgende tanke: Jeg, som psykoanalytiker, tenker at psyken opererer samtidig med motstridende krefter. I forhold til denne saken, vil jeg si at følelsen av å være «inkludert» og «oss/dem» kan eksistere side ved side av hverandre. Personlig tror jeg at enhver innvandrer må leve med dette resten av sitt liv. En person kan faktisk pendle frem og tilbake fra disse to posisjoner i løpet av en arbeidsdag (dette har jeg både hørt fra kolleger og opplevd selv). Poenget mitt er at jeg tror en opplevelse av å være totalt og fullstendig inkludert er uoppnåelig, mer et ideal vi kan strebe etter, som aldri blir en realitet - i hvert fall i psyken. Jeg tror både den etnisk norske og den utenlandske legen må forholde seg til og reflektere over den spenningen som oppstår i møtet mellom dem.

\section{Shahram Shaygani}

shaygani@hotmail.com

Shahram Shaygani (f. 1968) er psykiater og overlege ved Trasoppklinikken. Ingen oppgitte interessekonflikter.

\section{Re: Typisk vekstmønster for malignt pleuralt mesoteliom}

I Tidsskriftet nr. 11/2015 beskriver Arne Stenrud Berg og medarbeidere diagnostisk utredning av en pasient med malignt pleuralt mesoteliom (1). Hensikten er å selektere «pasienter med begrenset sykdom for kirurgi». De skriver at pasienten, en mann i 60-årene, «hadde vært eksponert for asbest i noen uker i 1970-årene og hadde røykt fra 15 års alder». Det blir opplyst at sykdommen vanligvis er yrkesrelatert, knyttet til asbesteksponering og at sykdommen påvises årlig hos ca. 50-70 menn og ca. 15 kvinner i Norge (1).

Sammenhengen mellom sykdommen og tidligere asbesteksponering ble internasjonalt akseptert i 1960-årene. Da ble de første tilfellene påvist og godkjent som yrkessykdom i Norge (2). På grunn av den lange latenstiden (10-50 år) har mesoteliominsidensen vært økende frem til i dag $(3,4)$. Det er ikke dokumentert andre årsaker enn asbest, heller ikke røyking, og sykdommen blir kalt en «signaltumor». Eksponering i barneårene fra det ytre miljø eller fra familiemedlemmer som var eksponert, blir lett oversett.

De fleste tilfeller av malignt pleuralt mesoteliom må vurderes som yrkessykdom, som gir rett til spesielle økonomiske ytelser både fra NAV og fra siste arbeidsgivers forsikringsselskap (2). Pasienten må selv, med hjelp av fastlegen, kreve å få sykdommen godkjent som yrkessykdom ved det lokale NAV-kontor og hos forsikringsselskapet.

Asbest ble forbudt i Norge i 1984. Arbeidere kan fortsatt bli utsatt for asbest og sykdomsrisiko under riving, reparasjon og ombygging. I bygg som er satt opp eller rehabilitert i perioden 1960-1975, er det stor risiko for å støte på asbest. Også i litt nyere bygg kan det forekomme (5). Fortsatt er forebygging mye viktigere enn behandling. Arbeidsgivere har plikt til å undersøke om det er asbest i bygget før slikt arbeid settes i gang, men mange dropper forundersøkelsene av uvitenhet eller for å spare penger. Det er av 
interesse å få mer informasjon om mannens yrke og tidligere bedrift.

\section{Nils Gunnar Mowe \\ nigunmo@online.no \\ Ebba Wergeland}

Nils Gunnar Mowe (f. 1929) er dr.med. og pensjonert spesialist i indremedisin og arbeidsmedisin. Hans doktoravhandling fra 1986 hadde tittelen: «Malignant mesothelioma in Norway. Epidemiological, aetiological and medico-legal aspects».

Ingen oppgitte interessekonflikter

Ebba Wergeland (f. 1946) er dr.med. og overlege i Arbeidstilsynet. Ingen oppgitte interessekonflikter.

\section{Litteratur}

1. Berg AS, Løndalen A, Brustugun OT. Typisk vekstmønster for malignt pleuralt mesoteliom. Tidsskr Nor Legeforen 2015; 135: 1050

2. Mowé G, Gylseth B. Medico-legal aspects of malignant mesothelioma. Scand J Soc Med 1984; 12: 15-23.

3. Mowé G, Tellnes G, Andersen A. Malignant pleural mesothelioma in Norway 1960-1992. Tidsskr Nor Lægeforen 1995; 115: 706-9.

4. Kreftregisteret. Kreftstatistikk. www.kreftregisteret.no/no/Registrene/ Kreftstatistikk/ (13.8.2015)

5. Johansen B, Evje M, Tesli J. Asbesthåndboka. Oslo: Gyldendal, 2008.

\section{Re: Hvem var Pylorica?}

Mange blant oss husker stadig «Pylorica», portnersken ved Anatomisk institutt i Domus Media, som det første levende mennesket vi møtte under «inntoget» i Anatomisk institutt ved studiets begynnelse. En stor takk til forfatter Rannveig Nordhagen som nå har løftet henne frem i rampelyset (1), der hun må få beholde sin selvfølgelige plass i vår hjemlige medisinskhistoriske fortelling.

\section{Jacob Klafstad \\ jklaf@broadpark.no}

Jacob Klafstad (f. 1934) er pensjonert spesialist i maxillo-facial kirurgi. Ingen oppgitte interessekonflikter

\section{Litteratur}

1. Nordhagen R. Hvem var Pylorica? Tidsskr Nor Legeforen 2015; 135: 1167 -9.

\section{R. Nordhagen svarer:}

Jeg er glad for at noen setter pris på at jeg har minnet om en av våre hverdagsslitere, som vi møtte under studietiden. Vi blir nok færre og færre som husker henne, men kanskje også yngre leger kan ha glede av å lese om henne.

\section{Rannveig Nordhagen}

roge.nordhagen@gmail.com

Rannveig Nordhagen (f. 1933) er pensjonert overlege.

Ingen oppgitte interessekonflikter.

\section{Re: Sommerferie på hospitalet}

I denne kommentaren påpeker forfatteren at sykepleiere presenterer seg med kun fornavn (1). Jeg er sykepleier med noen års erfaring fra kirurgisk, medisinsk og psykiatrisk avdeling. Jeg benytter konsekvent kun fornavn. Etternavnet på ID-kortet har jeg dekket til, noe som er imot retningslinjene, men jeg gjør det for egen sikkerhet. Jeg har opplevd trusler tidligere. Oftest er det sykepleiere som må utføre tiltak en lege har bestemt, tiltak som i noen tilfeller hvor det foreligger psykiatri, kan bli tatt dårlig i mot av pasienten. For- fatteren nevner ingenting om presentasjon hadde sammenheng med profesjonaliteten han opplevde. Jeg jobber tett på pasienter og ønsker å skille mellom jobb og privatliv. I dagens samfunn blir man fort googlet og stalket på nett. Det ønsker jeg å redusere sjansen for.

Lars Tufte

tufte.lars@gmail.com

Lars Tufte (f. 1977) er sykepleier på Oslo universitetssykehus.

Ingen oppgitte interessekonflikter.

Litteratur

1. Nakken KO. Sommerferie på hospitalet. Tidsskr Nor Legeforen 2014; 134: 2318.

\section{Re: Kreasjonismen er aldri morsom}

Kjell Johannes Tveter er uenig høgskolelektor Erik Tunstads anmeldelse av Edward Caudills bok «Intelligently designed» (1). Tunstads oppfatning og Caudills bok har etter min mening helt rett i sin analyse: Intelligent design (ID) er på alle måter en skjult variant av kreasjonisme. Dette er avdekket i flere artikler (2) og er akseptert viten $(3,4)$. Til kontrast mener Tveter at ID er en «vitenskapelig retning» til tross for at en rekke større nasjonale og internasjonale vitenskapelige organisasjoner eksplisitt har avvist ID som pseudovitenskapelig (5). Blant 3748 tilfeldig utvalgte forskere i American Association for the Advancement of Science er det $98 \%$ som er enige $i$ at mennesker og andre levende organismer evolverte over tid, ifølge Pew Research (6). Det er få problemstillinger i vitenskapen hvor man finner en slik konsensus på tvers av disipliner.

Hovedproblemet mener jeg er at ID ikke tilbyr testbare hypoteser, men er tilfreds med å påpeke nåværende uvitenhet $\mathrm{i}$ vitenskapen som evidens for sin egen fortreffelighet. Dette er sammenlignbart med å påpeke manglende kunnskap og deretter rope «Eureka» - uten å ha en testbar forklaringsmodell, også kjent som argumentum ad ignorantiam. ID-bevegelsen er med andre ord vitenskapelig ubrukelig og filosofisk forvirret (7).

Tveter oppgir ingen interessekonflikter, men han tjener nok penger på sin egen bok, «Livet - skapelse eller tilfeldighet», der han argumenterer på linje med ID-bevegelsen. Allerede i tittelen kan en alvorlig misforståelse av Darwins naturlige seleksjon enses - den er alt annet enn tilfeldig. Ofte er ID-argumenter, og tilsynelatende Tveters (8), allerede tilbakevist $(7,9)$. For eksempel er de fleste kreasjonist/ID-argumentene indeksert ved TalkOrigins.org, som tilbyr en rekke artikler og essays med dokumentasjon mot de mange tullete påstandene i denne politiske bevegelsen (9).

\section{Andreas Wahl Blomkvist}

andreas.wahl@gmail.com

Andreas Wahl Blomkvist (f. 1989) er medisinstudent ved Aalborg universitet.

Ingen oppgitte interessekonflikter.

Litteratur

1. Tunstad E. Kreasjonismen er aldri morsom. Tidsskr Nor Legeforen 2015; 135: 54

2. Forrest B. Understanding the intelligent design creationist movement: its true nature and goals. Center for Inquiry 2007. www.centerforinquiry.net/uploads/ attachments/intelligent-design.pdf (8.7.2015)

3. Wikipedia. Intelligent design. https://en.wikipedia.org/wiki/Intelligent design (8.7.2015)

4. Caudill E. Intelligently designed. Intelligently designed. Champaign, IL: University of Illinois Press, 2014.

5. Wikipedia. List of scientific bodies explicitly rejecting Intelligent design. https://en.wikipedia.org/wiki/List_of_scientific_bodies_explicitly_rejecting_ Intelligent_design (8.7.2015)

6. Funk C, Rainie L, Page D. Public and Scientists' Views on Science and Society. Pew Research Center. Jan 2015. www. pewinternet.org/files/2015/01/ PI ScienceandSociety Report 012915.pdf (14.8.2015).

7. Ruse M. Creationism. Stanford Encyclopedia of Philosophy. http://plato.stanford.edu/entries/creationism/\#IntDes (8.7.2015). 